\title{
1 Linear Infrastructure Drives Habitat Conversion and Forest Fragmentation Associated \\ 2 with Marcellus Shale Gas Development in a Forested Landscape
}

4 Lillie A. Langlois 1

5

Department of Ecosystem Science and Management, The Pennsylvania State University,

7 University Park, PA 16802, USA

$8 \quad{ }_{1}$ Corresponding Author; Email: $\underline{\text { lal276@psu.edu }}$

9 Patrick J. Drohan

10 Department of Ecosystem Science and Management, The Pennsylvania State University,

11 University Park, PA 16802, USA

12 Margaret C. Brittingham

13 Department of Ecosystem Science and Management, The Pennsylvania State University,

14 University Park, PA 16802, USA

\section{Abstract}

17 Large, continuous forest provides critical habitat for some species of forest dependent wildlife.

18 The rapid expansion of shale gas development within the northern Appalachians results in direct

19 loss of such habitat at well sites, pipelines, and access roads; however the resulting habitat

20 fragmentation surrounding such areas may be of greater importance. Previous research has

21 suggested that infrastructure supporting gas development is the driver for habitat loss, but

22 knowledge of what specific infrastructure affects habitat is limited by a lack of spatial tracking of

23 infrastructure development in different land uses. We used high-resolution aerial imagery, land

24 cover data, and well point data to quantify shale gas development across four time periods (2010, 
25 2012, 2014, 2016), including: the number of wells permitted, drilled, and producing gas (a

26 measure of pipeline development); land use change; and forest fragmentation on both private and

27 public land. As of April 2016, the majority of shale gas development was located on private land 28 (74\% of constructed well pads); however, the number of wells drilled per pad was lower on 29 private compared to public land (3.5 and 5.4, respectively). Loss of core forest was more than 30 double on private than public land (4.3 and $2.0 \%$, respectively), which likely results from better 31 management practices implemented on public land. Pipelines were by far the largest contributor 32 to the fragmentation of core forest due to shale gas development. Forecasting future land use 33 change resulting from gas development suggests that the greatest loss of core forest will occur

34 with pads constructed farthest from pre-existing pipelines (new pipelines must be built to 35 connect pads) and in areas with greater amounts of core forest. To reduce future fragmentation, 36 our results suggest new pads should be placed near pre-existing pipelines and methods to 37 consolidate pipelines with other infrastructure should be used. Without these mitigation 38 practices, we will continue to lose core forest as a result of new pipelines and infrastructure 39 particularly on private land.

40 Keywords

41 Core forest, forest fragmentation, linear infrastructure, Marcellus Shale, shale gas development 42 Introduction

43 Global and national demand for fossil fuels combined with improved technology of 44 hydraulic fracturing and horizontal well drilling led to the recent boom of the shale gas industry. 45 Although unconventional gas extraction technology has existed for several decades, large-scale 46 production only became widespread since 2000 , transforming the global energy portfolio. In the 47 continental United States, shale gas resources are widespread with 20 plays underling more than 
4830 states (USEIA 2016). The Marcellus Shale is the largest (covering over $124,000 \mathrm{~km}^{2}$ ) located

49 in the northern Appalachian region and currently the most prolific formation in the nation

50 (USEIA 2016). Pennsylvania is in the heart of the activity comprising 44 percent of the play

51 (Blohm et al. 2012) with currently almost 10,000 drilled wells (PADEP 2016a) and is slated for

52 substantial continued growth with an additional 8,000 permitted wells (PADEP 2016b).

53 The development of shale gas resources is recognized as an important driver of landscape

54 change (Pickell et al. 2014, Moran et al. 2015). Hydraulic fracturing in heavily forested areas

55 such as the northern Appalachian Basin often results in a large increase in industrial activity in

56 relatively undeveloped areas and the loss of forest cover and habitat fragmentation by placing

57 infrastructure in previously contiguous forest. Each well pad requires clearing on average 2.6 ha

58 for the stone pad surface (Drohan and Brittingham 2012, Jantz et al. 2014) and an additional 2.3

59 ha for the associated infrastructure (e.g. access roads, pipelines, water impoundments) (Johnson

60 et al. 2010). Multiple wells can be placed on a single pad allowing gas extraction from several

61 surrounding square kilometers, thereby dispersing pads and disturbance across a broad landscape

62 (Walton and Woocay 2013) referred to as energy sprawl (McDonald et al. 2009). Pads are not

63 randomly located and higher elevations have increased probability of pad placement, which are

64 generally more forested in the northern Appalachians (Meng 2014). An early statewide

65 assessment from this region in Pennsylvania estimated 1,400 ha of forest was cleared as of 2008

66 and final build out scenarios predicted as much as 15,000 to 36,000 ha could be cleared by 2030

67 (Johnson et al. 2010). Habitat fragmentation has been documented in the Marcellus and other

68 shale plays with core forest (defined as forest embedded within forested vegetation and beyond

69 the depth of edge influence) lost at twice the rate of overall forest loss (Slonecker et al. 2012,

70 Racicot et al. 2014, Moran et al. 2015, Farwell et al. 2016). Early assessments of Pennsylvania 
71 found approximately 25 percent of drilled and permitted pads are developed in core forest

72 resulting in the loss of 695 ha of core forest (Drohan et al. 2012).

73 Pipelines and roads have recently been recognized as primary drivers of the shale gas

74 footprint (Racicot et al. 2014, Farwell et al. 2016, USDOE 2016). However, many landscape

75 studies do not incorporate pipelines and focus primarily on well pads (Drohan et al. 2012, Jantz

76 et al. 2014, Unger et al. 2015) because pad location is the only data that is publicly available.

77 Including linear infrastructure requires aerial imagery and time-consuming hand digitizing.

78 However, studies that do not incorporate linear features are problematic because they greatly

79 underestimate the potential impacts of the industry. Furthermore, habitat fragmentation resulting

80 from roads and industrial linear corridors (powerline, pipeline, and seismic lines) in forested

81 landscapes can have many impacts on wildlife populations. Forest edges created by corridors

82 have higher rates of predation compared to interior forest for some species (Latham et al. 2011,

83 DeGregorio et al. 2014). Barrier effects created by linear corridors can restrict movement for

84 some wildlife species (Goosem and Marsh 1997, McGregor et al. 2008), alter home ranges

85 (Machtans 2006, Yokochi et al. 2015), and decrease gene flow and genetic diversity (Delaney et

86 al. 2010, Holderegger and Giulio 2010). Linear corridors may also be used as travel corridors for

87 some species (Latham et al. 2011) or facilitate the invasion of exotic species into previously

88 inaccessible habitat (Laurance et al. 2009, Mortensen et al. 2009).

$89 \quad$ Gas development strategy and infrastructure siting may vary based on location due to

90 objectives and management policies of the landowner. For example, the Bureau of Forestry,

91 Department of Conservation and Natural Resources (DCNR) manages gas development on state

92 forestland with a primary goal to manage infrastructure to reduce surface disturbance and

93 minimize impacts to other state forest uses and values (PADCNR 2014). Multiple measures of 
94 infrastructure consolidation are implemented on state forestland, which may reduce the overall

95 habitat fragmentation. In contrast to private land where the vast majority of gas development

96 occurs (Drohan et al. 2012), thousands of individual landowners manage development

97 independently and likely without an objective to reduce habitat fragmentation.

98 Our objectives were to: 1) quantify the spatial footprint of shale gas infrastructure

99 especially in relation to linear features like pipelines; 2) quantify habitat fragmentation and loss

100 of core forest resulting from gas infrastructure development; 3) compare gas infrastructure

101 development between private and public land (state forest and state gamelands); and 4) calculate

102 effects of pad placement (and necessary supporting infrastructure) on potential loss of core forest

103 due to future shale gas development. Our study area was selected because it provides a

104 representative sample of the heavily forested region of the northern Appalachians underlain by

105 the Marcellus shale and available to gas development. Furthermore, spatial impact assessments

106 are important for improving understanding of the effect of this specific forest disturbance on

107 northern Appalachian ecosystems and can be used in future cumulative impact assessments in

108 relation to other disturbances like forestry or mining.

109 We hypothesize that pipelines will be the primary cause of fragmentation and that

110 fragmentation will be less on public land compared to private due to various mitigation strategies

111 enacted by state agencies to minimize surface impacts from infrastructure. We also hypothesize

112 that loss of core forest will be greatest for wells located furthest from existing pipeline

113 infrastructure and located in areas with high amounts of core forest. Our research adds to an

114 earlier landscape study of Lycoming County by Slonecker et al. (2013) by expanding the time

115 frame to 2016 and focusing on specific hypotheses about fragmentation. Moreover, our results 
can highlight current or anticipated land use changes, highlight areas with the greatest risk of core forest loss, and recommend future siting of gas infrastructure in forested habitat.

\section{Materials and Methods}

121 Study Area and Gas Development

122 Lycoming County is located in the northcentral region of the Pennsylvania in the 123 northern Appalachians and encompasses 3,182 $\mathrm{km}^{2}$. The majority of the county is underlain by 124 the Marcellus play $\left(2,750 \mathrm{~km}^{2}\right.$ or $\left.85 \%\right)$, of which is highly forested (84 \% prior to development 125 in 2005 (PGDC 2015a)). The Pennsylvania Department of Environmental Protection (DEP) 126 database reports Lycoming County ranks $5^{\text {th }}$ in the state for active well drilling (926 wells or 127 well density of 8.51 pads/100 km² as of April 2016 (PADEP 2016a)) and gas production 128 (PADEP 2016c). Lycoming County provides a representative sample of the northcentral region, 129 where neighboring counties (Clinton, Sullivan, and Tioga) within the shale play are $85 \%$ 130 forested with well density of 7.02 pads/100 $\mathrm{km}^{2}$ as of April 2016 (PADEP 2016a). Public land 131 within Lycoming County comprises $886.6 \mathrm{~km}^{2}(28 \%)$ of the county and is almost entirely 132 forested (98\%), while the remaining area is privately owned and $74 \%$ forested. Major industries 133 in the county are service and manufacturing. Residential and urban development is concentrated 134 across the southern region, much of which is outside of the Marcellus play (Fig. 1). Lycoming 135 County has a relatively low overall settlement of 36.9 people per square kilometer (U.S. Census 136 Bureau 2010a), and settlement within the shale play is generally limited to small towns, except 137 in the southeast corner that has more mixed land use. 
Using a landscape level analysis, we quantified the early changes in forest fragmentation and core forest resulting from shale gas extraction in Lycoming County. We delineated the industry's spatial footprint for three time periods (2010, 2012, and 2014) using aerial imagery and estimated the footprint for 2016 using the DEP database for well location and completion stage. High-resolution ortho-rectified aerial imagery allowed for accurate digitizing of shale gas 143 infrastructure using imagery from 2005 as beginning land use conditions given it predated shale 144 gas development in the county (i.e. 2007). Imagery for each time period was important to 145 accurately determine biannual change due to infrastructure construction because some types of 146 infrastructure may not be detectable in subsequent years in specific land cover classes (e.g., 147 buried pipelines in agriculture cover). Imagery for 2014 was used as the most current 148 measurement of spatial disturbance for well pads and secondary infrastructure. Imagery for 2005 149 and 2010 were acquired from Pennsylvania Geospatial Data Clearinghouse (PGDC 2015b,c), 1502012 imagery from Lycoming County Department of Planning and Community Development, 151 and 2014 imagery from Seneca Resources Corporation. All imagery was flown at approximately 152 the same time of year (leaf-off in spring) and has a spatial resolution of approximately $0.30 \mathrm{~m}$ 153 (range $0.15-0.48 \mathrm{~m}$ ). Using ArcGIS 10.1 (ESRI 2012), these data were brought into a 154 geographic information system (GIS) for spatial analysis. We analyzed the entire county to make 155 it comparable to similar recent analyses (Slonecker et al. 2013, Slonecker and Milheim 2015). 156 The study area was expanded with a $2 \mathrm{~km}$ buffer to allow landscape analyses of well pads 157 located near county borders, yet all metrics are reported within the county. 158 We screen digitized the following shale gas related infrastructure: well pad, water 159 impoundment, pipeline, other (compressor station, metering station, misc.), new and expanded (widened) gas access roads. Seismic lines (4-8 $\mathrm{m}$ wide) associated shale gas exploration and 
161 development can fragment habitat for a variety of species (Bayne et al. 2005, Latham et al. 2011); however, were only partially detectable in our study area with aerial imagery (e.g., within forest; PADCNR 2014) and thus considered beyond the scope of this study and not included in analyses. The limit of disturbance (LOD) referred to as the physical footprint of the as-built infrastructure in addition to the area where actual vegetation removal occurred to facilitate construction (PADCNR 2014) was digitized for all pad structures (well pad, water impoundment, and other) by digitizing the outline of the surface disturbance and/or vegetation removal surrounding each pad structure.

Polygon area for all infrastructure was calculated within an ArcGIS geodatabase. To determine length of linear features (pipelines and roads), polygons were converted to polylines using the Polygon to Centerline Tool for ArcGIS (Dilts 2015). Only one author (LAL) digitized and proofed all features to maintain consistency in data collection and processing. Additionally, we used the DEP database to identify wells at three different stages of development: permitted (total number of wells to be constructed but completion status is unknown), drilled (pad is constructed), and producing (pad is connected to pipeline and construction is complete) (PADEP $2016 a, b, c)$.

To update our analysis from our last year of aerial imagery (2014) to April 2016, we used DEP data to determine the location of new drilled and producing pads (15 and 18, respectively). Quantifying the predicted habitat impact of development through 2016 was a four-step process. First, drilled well data through April 30, 2016 was used to determine the location of all constructed pads. Second, the ArcGIS Near Analysis tool was used to measure the distance from all drilled pads to the nearest existing pipeline. Pads less than $0.8 \mathrm{~km}$ from existing pipelines were considered connected and had no further impact on habitat conversion and were ignored for 
185 unconnected pads by adding pads one at a time in order of distance to existing pipeline and

186 manually drawing straight lines to connect to the nearest existing pipeline or producing pad,

187 whichever was closer. This method allowed pipelines to connect to pads such that new pipeline

188 infrastructure affects subsequent pipelines and minimized overall pipeline length and assumed 189 gas operators shared infrastructure. Finally, new pads were buffered to 2.2 ha size and modeled 190 pipelines were buffered to $20 \mathrm{~m}$ width, the average size and width of pads and pipelines in our 191 study. 
subsurface rights agreements, we considered any development within the surface boundaries of public land as development on public land in our analyses.

We compared infrastructure development between landowners using the average spatial disturbance per pad, well pad size including LOD, and 3 measures of infrastructure consolidation: ratio of permitted wells per pad, average pipeline length associated with each well pad, and the percent of pipeline length adjacent to pre-existing or gas access roads. To calculate the ratio of wells per pad, we used well location data provided by shale gas permits issued (PADEP 2016b). We identified pads with permitted wells by creating a $50 \mathrm{~m}$ buffer around all well permits issued, dissolving all overlapping buffers, and separating them into individual pads using the Multipart to Singlepart spatial analyst tool (Drohan et al. 2012). We used the spatial join tool to count the number of permitted wells located within each pad buffer. We estimated the length of gathering pipeline connecting each pad to transport pipelines by assuming pads within $0.8 \mathrm{~km}(0.5 \mathrm{mi})$ of a gathering pipeline were connected to the pipeline (Johnson et al. 2011). Gathering pipelines were buffered $(0.8 \mathrm{~km}$ each side) to count the number of permitted pads that intersected the buffer. We divided the number of intersecting pads with permitted wells by the total length of gathering pipeline (Johnson et al. 2011). The percentage of pipeline length adjacent to roads was measured by creating a $40 \mathrm{~m}$ buffer around pre-existing roads and new gas access roads for each year of the analysis, which assumed pipeline polylines within $40 \mathrm{~m}$ of a road polyline were collocated. The length of road buffer that intersected pipelines determined the length of pipeline collocated with road. We use general linear models (GLM) to determine whether well pad size differed by landowner and the number of permitted wells per pad differed by landowner and time. Infrastructure development per individual pad were not available for the following measurements: spatial disturbance of associated infrastructure, length of gathering 
pipeline, and loss of core forest (described in the following section); therefore we could not compare differences by ownership statistically but instead averaged measurements by landowner. We compared pipeline length collocated with roads by percent of total pipeline length for each landowner.

Gathering pipeline rights-of-way (ROW) width was compared between public and private land for pipelines collocated or not collocated with pre-existing or new gas access roads. Pipeline polylines for all years were combined and partitioned into four categories: public with road, public without road, private with road, private without road. To ensure gathering pipelines were sampled (and not wider marketing or transport lines), we used the well pad as the sampling unit. We assumed that pipelines located near drilled pads were gathering lines, therefore, we used the Select by Location tool to identify all drilled pads within $100 \mathrm{~m}$ from each polyline category. A random number generator was used to identify 20 sampled pads per category; width of pipeline ROW and road (if present) for each pad was measured $200 \mathrm{~m}$ from pad edge using the Measure tool at a 1:400 map scale. Distance from pad edge was selected to ensure a representative ROW width not affected by well pad proximity. However, due to limited mileage of pipelines on public land without roads, few drilled pads were located within our criteria; therefore, we sampled pads up to $800 \mathrm{~m}$ from pipelines for this category, which allowed for 15 non-random samples. We used GLM to determine whether total ROW width differed by landowner and road collocation, each treated as 2 independent variables with 2 categories each.

Fragmentation Analysis

Land cover data from 2005 was used for the forest fragmentation analysis and assumed to represent land cover prior to shale gas development (PGDC 2015a). Within a ArcGIS geospatial 
environment, we used a process similar to the United States Geological Survey (USGS) method for updating land cover data to account for new shale gas infrastructure (Slonecker et al. 2013). The landscape fragmentation analysis could not be supported by the native $30 \times 30 \mathrm{~m}$ resolution of the land cover dataset due to the relatively small size of shale gas infrastructure features.

Therefore, we re-sampled the 2005 land cover dataset to a $5 \mathrm{~m} \mathrm{x} 5 \mathrm{~m}$ resolution (Abrahams et al. 2015). The land cover was reclassified into a binary layer indicating non-forest and forest cover (deciduous, evergreen, mixed deciduous and evergreen, and forest wetlands) (PGDC 2015a) and smoothed to reduce the significance of anomalous cells by applying a 9 x 9 cell low-pass majority filter twice. To account for roads, the most detailed road layer available was selected that best matched the time frame of the land cover (U.S. Census Bureau 2010b). Each road type was buffered to a polygon with the average width per type $(10-20 \mathrm{~m}$ wide $)$ and the underlying pixels were reclassified as non-forest. Roads with unclassified road type were comparable to hiking trails and generally not visible with high-resolution leaf-off aerial imagery and considered to have little impact on habitat fragmentation and excluded prior to the analysis. This eliminated $15 \%$ of all roads to total $>6,200 \mathrm{~km}$, which is still approximately $30 \%$ more detailed than other available datasets. To account for changes in land cover as a result of shale gas development, all digitized infrastructure was combined per post-development year (2010, 2012, 2014, and 2016) and cumulatively added to the 2005 land use raster by reclassifying the underlying pixels as nonforest habitat.

Using ArcGIS 10.1 with third-party Landscape Fragmentation tool v.2.0, we determined the forest fragmentation class for all time periods: 2005, 2010, 2012, 2014, and 2016. Fragmentation layer for 2005 was used to compare pre-development conditions. All postdevelopment layers were used to determine greatest biennial period of change in fragmentation 
due to gas development. Additionally, fragmentation layer for 2010 was used to establish the onset of shale gas development and compare with similar previous analyses (Slonecker et al. 2013), while 2016 was used to determine the most current fragmentation state and provide the baseline layer to predict additional loss of core forest due to future development described in the following section.

Our analyses resulted in three forest pattern classes: non-forest, edge forest, and core forest (Vogt et al. 2007). Core forest was defined as forested pixels that are at least $100 \mathrm{~m}$ from any other land cover class. The $100 \mathrm{~m}$ edge distance was chosen for this analysis due to its extensive use in habitat fragmentation studies (Drohan et al. 2012, Racicot et al. 2014, Farwell et al. 2016). To determine whether pad or linear infrastructure had greater impacts on forest fragmentation, we combined all pad (well pad, water impoundment, other) and all linear (pipeline, road) infrastructure separately and completed the landscape fragmentation analysis described above on each dataset. This method slightly overestimates the amount of core forest lost and is not directly comparable with prior fragmentation analyses; however, it is useful to identify the proportion of change resulting from each infrastructure type. Loss of core forest was averaged by infrastructure type to compare by landowner.

Loss of core forest from future gas development

To quantify how pad placement determines the amount of core forest lost, we used existing and permitted (but not producing) wells as of April 30, 2016 (PADEP 2016c) and measured the expected amount of loss associated with bringing the well to production (e.g., pad construction if needed, pipelines as needed). Because multiple wells may be placed on a single pad, we used the pad as the sampling unit instead of the well. We estimated the loss of core 
forest resulting from the completion of 110 pads, of which 50 required pads, 31 pipelines, and 29 both pad and pipelines. To estimate loss of core forest per pad, we included three variables that we assumed were influential: infrastructure needed (pad, pipeline, both), core forest surrounding pad location, and the distance the pad is from the nearest pre-existing pipeline (a measure of new pipeline needed).

Pads that required pad construction were buffered to 2.2 ha. Pipelines were modeled for each pad that required pipeline connection by drawing a straight line to the nearest pre-existing pipeline as of our 2016 screen-digitized data layer. This method assumes pipeline infrastructure is not shared between new pads because our primary interest was to identify loss of core forest per pad. Individual pipelines were labeled based on the pad identification number they connected and buffered to $20 \mathrm{~m}$ wide. Pads and pipeline polygons were merged and then dissolved by pad identification number. Finally, a $100 \mathrm{~m}$ buffer was created around each new pad/pipeline combination, which was used to clip the 2016 fragmentation layer. The number of core forest cells within each buffer was used to calculate total area of core forest lost per pad. This method assumes any core forest habitat within the buffer would be converted to edge forest or non-forest habitat. We measured the amount of pre-existing core forest surrounding each pad by clipping 315 the 2016 fragmentation layer to a $2 \mathrm{~km}$ buffer around each pad center. Distance from pad to 316 nearest pre-existing pipeline was measured using the ArcGIS Near Analysis tool.

317 We used Analysis of Variance (ANOVA) with post-hoc Tukey honest significant 318 difference (HSD) test to estimate loss of core forest for infrastructure needed. Since the three 319 variables used to estimate future loss of core forest per pad were highly correlated but each 320 measured something slightly different, we examined each variable separately. We used general 321 linear models to determine the relationship between pad location and distance to pre-existing 
pipeline with loss of core forest. If data appeared curvilinear by visual examination, we modeled it with a quadratic term and used the anova function in $\mathrm{R}$ to perform a drop in deviance $\chi$ squared test to determine whether the quadratic term improved the model. All statistical analyses were conducted in R Version 3.0.2 (R Development Core Team 2014). An alpha of 0.05 was used to indicate statistically significant differences, and an alpha of 0.10 was used to identify marginally significant relationships for future study.

\section{Results}

Shale gas development in Lycoming County began slowly in 2010, peaked in 2012, and 331 slowed down considerably by 2016. The construction of 926 wells on 234 pads and associated 332 infrastructure resulted in the total land conversion of 2,689 ha as of April 2016 (Table 1). Well 333 pad infrastructure became more consolidated through time from $2.2 \pm 0.2$ permitted wells per $334 \mathrm{pad}$ in 2010 to $4.4 \pm 0.2$ as of $2016\left(F_{1,957}=40.76, P<0.001\right)$ and public land had more 335 permitted wells per pad compared to private $\left(F_{1,957}=90.33, P<0.001\right.$; Fig. 2$)$. The majority of 336 shale gas infrastructure was constructed in forest $(2,278$ ha or $86.6 \%$ of land cover change), followed by agricultural (334 ha or $12.7 \%$ ). As of the most recent year of aerial imagery (2014), 338 the average spatial disturbance per well pad is 2.2 ha plus an additional 7.7 ha for secondary 339 infrastructure. Pipelines accounted for the single largest portion of the industry's spatial footprint 340 at $51 \%$ (563 km or 1,320 ha), while well pads accounted for the second largest portion (23\% or 341589 ha including the LOD). Additional secondary infrastructure included the expansion of 279 $342 \mathrm{~km}$ of existing roads (10\% or $250 \mathrm{ha}), 69$ water impoundments ( $7 \%$ or $191 \mathrm{ha}), 143 \mathrm{~km}$ of new 343 access roads ( $6 \%$ or 167 ha), and 72 other (compressor station, metering station, etc.; $3 \%$ or 72 344 ha). 


\section{Landowner patterns}

Gas development resulted in 198 well pads constructed on private land, 73 pads on state forestland, and 6 pads on state gamelands (henceforth combined as public land) through April 2016. These numbers differ from those based on DEP data (Table 1) because permits are associated with wells and not the actual pad and sometimes pads are constructed prior to obtaining well permits, as documented in other studies (Slonecker et al. 2013). Well pad density indicates the intensity of gas development and was slightly higher on private land compared to public (8.94 and 7.86 pads $/ 100 \mathrm{~km}^{2}$, respectively). The average spatial disturbance on private and public land was similar for well pads $\left(2.2 \pm 0.06\right.$ and $2.1 \pm 0.09$ ha, respectively; $F_{1,262}=$ $0.45, P=0.50)$. However, the associated infrastructure was approximately $25 \%$ greater on private land compared to public (8.4 and 5.8 ha, respectively). Because public land is almost entirely forested, shale gas development inherently resulted in the clearing of 645 ha of forest (97.8\% of total area converted). By contrast, $83.3 \%$ of infrastructure built on private land was constructed in previously forested area, which resulted in the clearing of 2410 ha of forest. Our fragmentation analysis indicates shale gas development resulted in more than twice the loss of core forest on private land compared to public (-4.3\% and $-2.0 \%$, respectively, Fig. 3).

362 Furthermore, our comparison of pad and linear infrastructure indicates no difference in the loss of core forest for pad infrastructure between public and private land (-1.0\% and $-0.9 \%$, respectively); however the majority of core forest lost resulted from linear construction on private land $(-4.0 \%)$ compared to public $(-1.7 \%)$. Although this comparison is an approximate estimate for loss of core forest, it demonstrates linear infrastructure accounts for the largest portion of fragmentation. 
All three measures of infrastructure consolidation investigated indicate greater consolidation took place on public land compared to private land. The number of permitted wells per pad was significantly lower on private land compared to public $(4.0 \pm 0.17$ and $5.9 \pm 0.32$ respectively as of April 2016, $F_{1,331}=26.15, P<0.001$; Fig. 2). The average length of gathering pipeline per pad on private land was $30 \%$ longer compared to public land $(2.8$ and $1.7 \mathrm{~km}$, 373 respectively). A smaller percentage of pipelines were collocated with roads on private compared 374 to public land (25\% and $81 \%$, respectively). Average gathering pipeline ROW width was 375 marginally lower for public land $(25.1 \pm 0.92 \mathrm{~m})$ compared to private land $\left(27.0 \pm 1.06 \mathrm{~m} ; F_{2,72}\right.$ $376=2.80, P=0.099)$, but was significantly wider $\left(F_{2,72}=13.24, P<0.001\right)$ when collocated with 377 roads $(28.3 \pm 0.92 \mathrm{~m})$ compared to pipelines without adjacent roads $(23.6 \pm 0.97 \mathrm{~m} ;$ Fig. 4).

378 Forest Fragmentation

Prior to shale gas development in Lycoming County, the majority of the county could be classified as core forest habitat (67\%), followed by edge forest and non-forest (20\% and $13 \%$, respectively). Clearing forest for gas development indirectly affected the surrounding habitat by creating 9,162 ha of edge forest and the loss of 11,527 ha of core forest as of April 2016 (Fig. 3). 383 Core forest remained the dominant forest class of the county, however, decreased by nearly $4 \%$ 384 since drilling began in 2007. Linear infrastructure (pipeline and road) resulted in $3.2 \%$ loss of 385 core forest, while pad infrastructure (well pad, water impoundment, compressor station, etc.), 386 resulted in $0.9 \%$ loss of core forests.

388 Loss of core forest for future development 
The predicted amount of core forest which will be lost with the completion of a well differs depending on the type of infrastructure that is required to bring the well on line $\left(F_{2,107}=\right.$ 22.89, $P<0.001$; Fig. 5). Wells that require a new pipeline for completion will result in significantly higher $(P<0.001)$ rates of loss (need pipeline loss $=32.83 \pm 6.2$ ha; need both pad and pipeline loss $=34.04 \pm 4.2)$ than wells that required only pad construction $(5.19 \pm 0.6 \mathrm{ha})$.

394 There was no significant difference $(P>0.05)$ in amount of core forest lost between wells that required a pipeline but were placed on existing pad and those that required both a pad and pipeline (Fig. 5). We found a strong positive relationship between the predicted loss of core forest and the distance the well is from a pre-existing pipeline $\left(\mathrm{R}^{2}=80.7 \%, F_{1,108}=450.50, P<\right.$ 0.001; Fig. 6a). For every additional $500 \mathrm{~m}$ increase in distance, we expect loss to increase by an average of 8.1 ha. When examining the relationship between the predicted loss of core forest and the amount of core forest within $2 \mathrm{~km}$ of pad center, we found loss peaked at high levels of surrounding core forest. We evaluated a quadratic core forest term in our statistical model, which statistically improved the model fit to the data $\left(\chi_{1 \mathrm{df}}^{2}=9176.3, P<0.001\right)$. We found a significant positive relationship between the predicted loss of core forest and the amount of core forest within $2 \mathrm{~km}$ of pad center $\left(\mathrm{R}^{2}=41.7 \%, F_{2,108}=38.34, P<0.001\right.$; Fig. $\left.6 \mathrm{~b}\right)$. We expect pads placed within $40 \%$ core forest will lose on average 7.5 ha of core forest, while pads within $80 \%$ core forest will lose on average 34.9 ha of core forest. However, low values for core forest surrounding pads $(<30 \%)$ are likely not correct in our model due to the limited number of samples in these areas. Predicted loss of core forest in areas with limited surrounding core forest $(<30 \%)$ are likely not correct in our model due to the low number of samples in these areas.

\section{Discussion}


The majority of development in our study area occurred since 2010 (Slonecker et al. 2013) resulting in almost $4 \%$ loss of core forest within 6 years. Similar to other studies, we found that while a small portion of the total land area $(<0.1 \%)$ was directly converted for infrastructure, indirect impacts caused by habitat fragmentation were far greater (Racicot et al. 2014, Moran et al. 2015, Slonecker and Milheim 2015). Pipelines were found to comprise the 417 single largest portion of the industry's spatial footprint and have the largest effect on habitat 418 fragmentation. Similar to previous studies, we found the average footprint for secondary 419 infrastructure (pipeline, road, water impoundment, etc.) far exceeds the well pad footprint 420 (Schneider et al. 2003, Johnson et al. 2010, Slonecker et al. 2013, Abrahams et al. 2015). 421 However, our estimates for secondary infrastructure are more than twice the size of early studies 422 in the Marcellus shale play (Johnson et al. 2010, Slonecker et al. 2013) because development has 423 been extensive since those studies were conducted.

Forest was overwhelmingly the most impacted land cover in our study and conversion was proportional to available forest cover. Development in forest is characterized by high 426 permanence with the majority of the footprint remaining in a non-forested state, much of which 427 is subject to continued disturbance (Pickell et al. 2014). For example, pipeline rights-of-way are 428 regularly mowed to prevent tree and shrub growth that may damage buried pipes. Similar to 429 conventional gas development that is still evident on the landscape after many decades 430 (Slonecker and Milheim 2015), the persistence of land cover change and great dissimilarity 431 between developed areas and the surrounding forest results in a low probability that disturbed areas will revert back to a natural state in the near future (Marzluff and Ewing 2001).

433 We found gas development differed between landowner with a smaller footprint and 434 reduced habitat fragmentation on public compared to private land. We attribute these differences 19 
to public land benefiting from a variety of factors including expertise, landowner size, and the implementation of best management practices. DCNR has decades of experience managing conventional gas and oil extraction on state forestland, and a large team of staff devoted to shale gas development with expertise ranging from forestry, geology, and hydrology (PADCNR 2014).

DCNR is the largest landowner in the state, which likely provides an advantage for lease negotiations compared to relatively small private landholdings.

Large public landowners negotiated with a relatively small number of gas operators compared to private landowners (4 and 14 gas operators, respectively (PADEP 2016b)), therefore individual landowners can make deals with different operators such that two different operators end up working in close proximity and duplicating infrastructure on private land but not on public land. Lastly, multiple mitigation strategies are implemented on public land with the goal of reducing surface disturbance and impacts to forest. For example, DCNR can limit the number of well pads per leased track (PADCNR 2014). This method constrains development intensity (i.e., pad density) and encourages operators to increase the number of wells per pad thereby maximizing per well drainage and efficiency (USDOE 2016). Another policy is to place pads close to existing roads and to cluster pads to minimize overall forest disturbance (Drohan et al. 2012).

453 utilize existing surface disturbance whenever feasible, including road networks, right-of-way 454 corridors, or abandoned mine lands (PADCNR 2014). We found support for this policy with the 455 majority of pipelines collocated with roads on public land but not on private land. However, 456 DCNR faces conflicting goals when deciding whether to collocate roads and pipelines due to the 457 various and occasionally opposing uses of public land (PADCNR 2014). Collocation makes gas 20 
infrastructure more visible to the public and reduces the wild character of the road, which is a concern for the bureau because scenic driving is one of the largest recreational use of state forest land (PADCNR 2014). Another concern is the potential increase in corridor width, which could alter wildlife movement patterns depending on whether species perceive it as a barrier (Bayne et al. 2005, Latham et al. 2011, Latham and Boutin 2015). Our results suggest collocating pipelines with gas access roads increased corridor width by approximately $5 \mathrm{~m}$ compared to pipelines without adjacent roads. Although not we did not find a significant difference in corridor width between landowners, there is a trend for narrower corridors on public land compared to private land that likely represents an actual difference. DCNR implements measures to minimize corridor width where adjacent roads substitute as temporary workspace that is required to facilitate pipeline construction. For example, DCNR has restricted corridor width on several recently constructed pipelines collocated with roads to approximately $10 \mathrm{~m}$ wide (Ben Gamble, DCNR, pers. comm.), which is less than half of the average width of collocated corridors found in this study. Therefore, the technology exists to collocate pipelines without requiring a tradeoff between increased corridor width and reduced habitat fragmentation.

Linear infrastructure on private land contributed to the greatest loss of core forest. Unlike 474 private land, we found the majority of pipelines on public land were collocated with roads, which 475 likely reduced habitat fragmentation. Similarly, Abrahams et al. (2015) found that requiring 476 pipelines to follow existing roads prevented further fragmentation in a core forested region while 477 allowing full extraction of the shale resource. Collocation is widely accepted as an effective mitigation strategy to reduce surface impacts (Bearer et al. 2012, Racicot et al. 2014), however, we found that it rarely occurred for the majority of our study area (i.e., private land). 
the shale gas industry. To facilitate gas development, roads receive high traffic volume and vehicles hauling heavy loads. Pre-existing traditional forest roads are not compatible and require significant improvement to the road surface, sub-base, and drainage. The majority of private and public roads expanded to facilitate gas development were within forest cover and previously 3 $4 \mathrm{~m}$ wide with closed tree canopy and limited traffic. Roads are generally expanded to $6-12 \mathrm{~m}$ wide to facilitate gas development (PADCNR 2014, NYSDEC 2015), resulting in corridors that break the forest canopy, which can alter wildlife movement (Yokochi et al. 2015), fragment wildlife populations (Goosem and Marsh 1997), and change microclimate conditions (Matlack 1993, Gehlhausen et al. 2000). Furthermore, increased traffic on forest roads will result in higher rates of mortality for a variety of forest dwelling species (Fahrig et al. 1995, Forman and Alexander 1998, Gibbs and Shriver 2005) and reduced wild character value (PADCNR 2014).

Our results identified new pipeline construction as the greatest driver of core forest lost with future gas development. To reduce future fragmentation in forested areas, our results suggest new pads should be placed near existing pipelines and methods to consolidate pipelines with other infrastructure should be used. Development should be avoided in areas remote from pipelines and in areas with extensive core forest. Other ways to reduce fragmentation have been demonstrated by limiting well density on the landscape either by increasing the number of wells per pad (Johnson et al. 2010, Jantz et al. 2014, Baranzelli et al. 2015) or increasing the length of lateral lines for gas extraction (Abrahams et al. 2015). Requiring multiple gas operators to share pipeline rights-of-way can reduce overall pipeline length and prevent redundant lines.

Furthermore, pipelines can be placed under roads to minimize habitat conversion and corridor width.

We believe our estimation for habitat fragmentation in the study area is conservative. We 
measured all gas infrastructure for the first 3 time periods of our study, but pad and pipeline construction was estimated for only the final year (2016) using DEP gas production data. Furthermore, we assumed a minimum of pipeline construction by ensuring gas operators shared pipeline infrastructure and new pipeline construction utilized the shortest possible distance to connect well pads with existing pipelines. These estimates allowed us to provide baseline estimates for the final year of our study. Conservative estimates to fully extract the shale resource indicate development intensity (i.e., well density) could be more than 4 times greater than current levels in Lycoming County (Davis and Robinson 2012, NYSDEC 2015). Given shale gas development in the early stages and more than $70 \%$ of the remaining resource to be developed (Habicht et al. 2015), our estimates are far below predictions to fully exploit the resource.

Limiting loss of core forest and fragmentation is of particular importance in Pennsylvania and central Appalachia due to potential impacts to area sensitive species (Brittingham and Goodrich 2010, Brittingham et al. 2014, Barton et al. 2016, Farwell et al. 2016) and ecosystem services (Evans and Kiesecker 2015). Similar to other studies, we believe landscape level (Bearer et al. 2012) and site specific planning (Milt et al. 2015) is required to minimize impacts from gas development. Drohan et al. (2012) suggest regional planning geared towards private landowners to help manage development and the siting of infrastructure could help preserve remaining areas of core forest. We suggest pipeline data should be made publicly available similar to well location data to aid regional planning of future gas development and minimize additional pipeline construction. Our results suggest new pads should be sited near existing pipelines to reduce new pipeline construction and to avoid constructing new pads in areas surrounded by core forest due to the greater fragmentation effect compared to pads placed in 
more disturbed areas. We suggest collocating pipelines with existing roads in areas of high core forest to reduce further fragmentation.

\section{Conclusion}

Our results suggest substantial changes in landscape composition have occurred with shale gas development resulting in nearly $4 \%$ core forest lost within 6 years. Loss of core forest was more than double on private land compared to public land due to lack of infrastructure consolidation on private land. Pipelines comprise the single largest component of the industry's spatial footprint and are the major fragmenting feature. New pipeline construction was the largest driver of core forest lost for future gas development. To reduce future fragmentation in forested areas, our results suggest new pads should be placed near pre-existing pipeline infrastructure, new pipeline construction should be minimized, and methods to reduce the fragmenting effects of pipelines should be implemented.

\section{Acknowledgements}

We thank Joseph Bishop, John Brodnicki, Rick Day, Benjamin Gamble, Sarah Johnson, and Doug Miller for GIS assistance. We thank Courtney Davis and Tyler Wagner for statistical assistance. We thank the following individuals for assistance throughout the project: Abigail Barenblitt, Ethan Barton, Nathan Fronk, and Andrew Weber. We thank Lycoming County Department of Planning and Community Development and Seneca Resources Corporation for 547 aerial imagery. This work was supported by the USDA National Institute of Food and 
4548 Agriculture, Hatch project 1002595. Funding for this project was provided by the Bureau of 6

7549 Forestry of Pennsylvania Department of Conservation and Natural Resources, the Heinz

8

9550 Endowments, the Pennsylvania Game Commission through the State Wildlife Grant (SWG) 552 Agricultural Sciences at The Pennsylvania State University. 


\section{Literature Cited}

Abrahams, L. S., W. M. Griffin, and H. S. Matthews. 2015. Assessment of policies to reduce core forest fragmentation from Marcellus shale development in Pennsylvania. Ecological Indicators 52:153-160.

Baranzelli, C., I. Vandecasteele, R. R. Barranco, I. Mari i Rivero, N. Pelletier, O. Batelaan, and C. Lavalle. 2015. Scenarios for shale gas development and their related land use impacts in the Baltic Basin, northern Poland. Energy Policy 84:80-95.

Barton, E. P., S. E. Pabian, and M. C. Brittingham. 2016. Bird community response to Marcellus shale gas development. Journal of Wildlife Management 80:1301-1313.

Bayne, E. M., S. Boutin, B. Tracz, and K. Charest. 2005. Functional and numerical responses of ovenbirds (Seiurus aurocapilla) to changing seismic exploration practices in Alberta's boreal forest. Ecoscience 12:216-222.

Bearer, S., E. Nicholas, T. Gagnolet, M. DePhilip, T. Moberg, and N. Johnson. 2012. Evaluating the scientific support of conservation best management practices for shale gas extraction in the Appalachian Basin. Environmental Practice 14:308-319.

Bishop, J. A. 2008. Temporal dynamics of forest patch size distribution and fragmentation of habitat types in Pennsylvania. Dissertation. The Pennsylvania State University, PA, USA.

Blohm, A., J. Peichel, C. Smith, and A. Kougentakis. 2012. The significance of regulation and land use patterns on natural gas resource estimates in the Marcellus shale. Energy Policy $50: 358-369$.

Brittingham, M. C., and L. J. Goodrich. 2010. Habitat fragmentation: a threat to Pennsylvania's forest birds. Pages 205-216 in S. K. Majumdar, T. L. Master, M. C. Brittingham, R. M. Ross, R. S. Mulvihill, and J. E. Huffman, editors. Avian ecology and conservation: a 
Pennsylvania focus with national implications. The Pennsylvania Academy of Science.

Brittingham, M. C., K. O. Maloney, A. M. Farag, D. D. Harper, and Z. H. Bowen. 2014.

Ecological risks of shale oil and gas development to wildlife, aquatic resources and their habitats. Environmental Science \& Technology 48:11034-11047.

Davis, J. B., and G. R. Robinson. 2012. A geographic model to assess and limit cumulative ecological degradation from Marcellus Shale exploitation in New York, USA. Ecology and Society 17:25.

DeGregorio, B. A., P. J. Weatherhead, and J. H. Sperry. 2014. Power lines, roads, and avian nest survival: effects on predator identity and predation intensity. Ecology and Evolution 4:15891600.

Delaney, K. S., S. P. D. Riley, and R. N. Fisher. 2010. A rapid, strong, and convergent genetic response to urban habitat fragmentation in four divergent and widespread vertebrates. PloS ONE 5:e12767-11.

Dilts, T. E. 2015. Polygon to Centerline Tool for ArcGIS. http://www.arcgis.com/home/item.html?id=bc642731870740aabf48134f90aa6165. Accessed May 2015.

Drohan, P. J., and M. Brittingham. 2012. Topographic and soil constraints to shale-gas development in the northcentral Appalachians. Soil Science Society of America Journal 76:1696-1706.

Drohan, P. J., M. Brittingham, J. Bishop, and K. Yoder. 2012. Early trends in landcover change and forest fragmentation due to shale-gas development in Pennsylvania: a potential outcome for the northcentral Appalachians. Environmental Management 49:1061-1075.

ESRI. 2012. Environmental Systems Research Institute, ArcGIS v.10.1. Redlands, CA. 
Evans, J. S., and J. M. Kiesecker. 2015. Shale gas, wind and water: assessing the potential cumulative impacts of energy development on ecosystem services within the Marcellus play. PLoS ONE 9:e89210.

Fahrig, L., J. H. Pedlar, S. E. Pope, P. D. Taylor, and J. F. Wegner. 1995. Effect of road traffic on amphibian density. Biological Conservation 73:177-182.

Farwell, L. S., P. B. Wood, J. Sheehan, and G. A. George. 2016. Shale gas development effects on the songbird community in a central Appalachian forest. Biological Conservation 201:7891.

Forman, R., and L. Alexander. 1998. Roads and their major ecological effects. Annual Review of Ecology and Systematics 29:207-231.

Gehlhausen, S. M., M. W. Schwartz, and C. K. Augspurger. 2000. Vegetation and microclimatic edge effects in two mixed-mesophytic forest fragments. Plant Ecology 147:21-35.

Gibbs, J. P., and W. G. Shriver. 2005. Can road mortality limit populations of pool-breeding amphibians? Wetlands Ecology and Management 13:281-289.

Goosem, M., and H. Marsh. 1997. Fragmentation of a small-mammal community by a powerline corridor through tropical rainforest. Wildlife Research 24:613-629.

Habicht, S., L. Hanson, and P. Faeth. 2015. The potential environmental impact from fracking in the Delaware River basin. C.N.A. Analysis and Solutions, Arlington, VA, USA.

Holderegger, R., and M. Di Giulio. 2010. The genetic effects of roads: a review of empirical evidence. Basic and Applied Ecology 11:522-531.

Jantz, C. A., H. K. Kubach, and J. R. Ward. 2014. Assessing land use changes due to natural gas drilling operations in the Marcellus Shale in Bradford County, PA. The Geographical Bulletin 55:18-35. 
Johnson, N., T. Gagnolet, R. Ralls, and J. Stevens. 2011. Natural gas pipelines: excerpt from Report 2 of the Pennsylvania energy impacts assessment. The Nature Conservancy. http://www.nature.org/ourinitiatives/regions/northamerica/unitedstates/pennsylvania/ngpipelines.pdf. Accessed May 2011.

Johnson, N., T. Gagnolet, R. Ralls, E. Zimmerman, B. Eichelberger, C. Tracey, G. Kreitler, S. Orndorff, J. Tomlinson, S. Bearer, and S. Sargent. 2010. Pennsylvania energy impacts assessment. The Nature Conservancy. http://www.nature.org/media/pa/pa_energy_assessment_report.pdf. Accessed May 2011.

Latham, A. D. M., M. C. Latham, M. S. Boyce, and S. Boutin. 2011. Movement responses by wolves to industrial linear features and their effect on woodland caribou in northeastern Alberta. Ecological Applications 21:2854-2865.

Latham, A. D. M., and S. Boutin. 2015. Impacts of utility and other industrial linear corridors on wildlife. R. van der Ree, D. J. Smith, and C. Grilo, editors. Handbook of road ecology. First Edition. John Wiley \& Sons, Ltd.

Laurance, W. F., M. Goosem, and S. G. W. Laurance. 2009. Impacts of roads and linear clearings on tropical forests. Trends in Ecology \& Evolution 25:659-669.

Machtans, C. S. 2006. Songbird response to seismic lines in the western boreal forest: a manipulative experiment. Canadian Journal of Zoology 84:1421-1430.

Marzluff, J. M., and K. Ewing. 2001. Restoration of fragmented landscapes for the conservation of birds: a general framework and specific recommendations for urbanizing landscapes. Restoration Ecology 9:280-292.

Matlack, G. R. 1993. Microenvironment variation within and among forest edge sites in the eastern United States. Biological Conservation 66:185-194. 
McDonald, R. I., J. Fargione, J. Kiesecker, W. M. Miller, and J. Powell. 2009. Energy sprawl or energy efficiency: climate policy impacts on natural habitat for the United States of America. PLoS ONE 4:e6802.

McGregor, R. L., D. J. Bender, and L. Fahrig. 2008. Do small mammals avoid roads because of the traffic? Journal of Applied Ecology 45:117-123.

Meng, Q. 2014. Modeling and prediction of natural gas fracking pad landscapes in the Marcellus Shale region, USA. Landscape and Urban Planning 121:109-116.

Milt, A. W., T. Gagnolet, and P. R. Armsworth. 2015. Synergies and tradeoffs among environmental impacts under conservation planning of shale gas surface infrastructure. Environmental Management 57:21-30.

Moran, M. D., A. B. Cox, R. L. Wells, C. C. Benichou, and M. R. McClung. 2015. Habitat loss and modification due to gas development in the Fayetteville Shale. Environmental Management 55:1276-1284.

Mortensen, D. A., E. S. J. Rauschert, A. N. Nord, and B. P. Jones. 2009. Forest roads facilitate the spread of invasive plants. Invasive Plant Science and Management 2:191-199.

NYSDEC. 2015. Final supplemental generic environmental impact statement on the oil, gas and solution mining regulatory program. New York State Department of Environmental Conservation; Bureau of Oil \& Gas Regulation, Division of Mineral Resources; http://www.dec.ny.gov/energy/45912.html. Accessed May 2016.

664 PADCNR. 2014. Shale-gas monitoring report. Pennsylvania Department of Conservation and $665 \quad$ Natural Resources. 666 http://www.dcnr.state.pa.us/cs/groups/public/documents/document/dcnr_20029147.pdf. Accessed November 2014. 
PADEP. 2016a. SPUD data report. Pennsylvania Department of Environmental Protection. http://www.depreportingservices.state.pa.us/ReportServer/Pages/ReportViewer.aspx?/Oil_G as/Spud_External_Data. Accessed May 2016.

PADEP. 2016b. Permits issued detail report. Pennsylvania Department of Environmental Protection. http://www.depreportingservices.state.pa.us/ReportServer/Pages/ReportViewer.aspx?/Oil_G as/Permits_Issued_Detail. Accessed May 2016.

PADEP. 2016c. Oil and gas reporting website - Production reports. Pennsylvania Department of Environmental Protection.

https://www.paoilandgasreporting.state.pa.us/publicreports/Modules/Welcome/Welcome.asp x. Accessed May 2016.

PGDC. 2013. Pennsylvania state forest lands. Pennsylvania geospatial data clearinghouse. http://www.pasda.psu.edu/uci/MetadataDisplay.aspx?entry=PASDA\&file=DCNR_BOF_Sta teForests201308.xml\&dataset=263. Accessed June 2014.

PGDC. 2015a. PAMAP program land cover for Pennsylvania, 2005. Pennsylvania geospatial data clearinghouse.

http://www.pasda.psu.edu/uci/MetadataDisplay.aspx?entry=PASDA\&file=palanduse05utm1 8nad83.xml\&dataset=1100. Accessed November 2015.

PGDC. 2015b. DCNR PAMAP Program 2005. Pennsylvania geospatial data clearinghouse. http://www.dcnr.state.pa.us/topogeo/pamap/. Accessed November 2015.

PGDC. 2015c. DCNR PAMAP Program 2010. Pennsylvania geospatial data clearinghouse. http://www.dcnr.state.pa.us/topogeo/pamap/. Accessed November 2015.

PGDC. 2015d. Pennsylvania state gamelands. Pennsylvania geospatial data clearinghouse. 
http://www.pasda.psu.edu/uci/MetadataDisplay.aspx?entry=PASDA\&file=PGC_StateGamel and2015.xml\&dataset=86. Accessed November 2015 .

Pickell, P., S. Gergel, N. Coops, and D. Andison. 2014. Monitoring forest change in landscapes under-going rapid energy development: challenges and new perspectives. Land 3:617-638.

R Core Team, 2014. R: a language and environment for statistical computing. R Foundation for Statistical Computing, Vienna, Austria.

Racicot, A., V. Babin-Roussel, J.-F. Dauphinais, J.-S. Joly, P. Noël, and C. Lavoie. 2014. A framework to predict the impacts of shale gas infrastructures on the forest fragmentation of an agroforest region. Environmental Management 53:1023-1033.

Schneider, R. R., J. B. Stelfox, S. Boutin, and S. Wasel. 2003. Managing the cumulative impacts of land uses in the Western Canadian Sedimentary Basin: a modeling approach. Conservation Ecology 7:8.

Slonecker, E. T., L. E. Milheim, C. M. Roig-Silva, A. R. Malizia, and B. H. Gillenwater. 2013. Landscape consequences of natural gas extraction in Fayette and Lycoming Counties, Pennsylvania, 2004-2010. U.S. Geological Survey Open File Report 2013-1119.

Slonecker, E. T., L. E. Milheim, C. M. Roig-Silva, A. R. Malizia, D. A. Marr, and G. B. Fisher. 2012. Landscape consequences of natural gas extraction in Bradford and Washington Counties, Pennsylvania. U.S. Geological Survey Open-File Report 2012-1154.

Slonecker, E., and L. Milheim. 2015. Landscape disturbance from unconventional and conventional oil and gas development in the Marcellus Shale region of Pennsylvania, USA. Environments 2:200-220.

U.S. Census Bureau. 2010a. State and county quickfacts: Lycoming County. http://www.census.gov/quickfacts/table/PST045215/42081. Accessed May 2016. 
4714 U.S. Census Bureau. 2010b. TIGER/Line® shapefiles all roads. https://www.census.gov/geo/maps-data/data/tiger-line.html. Accessed April 2014.

Unger, D., I.-K. Hung, K. Farrish, and D. Dans. 2015. Quantifying land cover change due to petroleum exploration and production in the Haynesville Shale region using remote sensing. International Journal of Applied Geospatial Research 6:1-17.

USDOE. 2016. Footprint reduction. U.S. Department of Energy, Office of Oil and Natural Gas.

USEIA. 2016. Annual energy outlook 2016. U.S. Energy Information Administration.

Vogt, P., K. H. Riitters, C. Estreguil, J. Kozak, T. G. Wade, and J. D. Wickham. 2007. Mapping spatial patterns with morphological image processing. Landscape Ecology 22:171-177.

Yokochi, K., B. K. Chambers, and R. Bencini. 2015. An artificial waterway and road restrict movements and alter home ranges of endangered arboreal marsupial. Journal of Mammalogy 96:1284-1294.

Walton, J., and A. Woocay. 2013. Environmental issues related to enhanced production of natural gas by hydraulic fracturing. Journal of Green Building 8:62-71. 
7

8

9732 County, Pennsylvania.

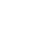

Table 1 Number of pads at three stages of shale gas development (permitted, drilled, producing) across time resulting in cumulative habitat conversion and loss of core forest in Lycoming

\begin{tabular}{rccccrc}
\hline & \multicolumn{3}{c}{ Number of pads $^{\mathrm{a}}$} & Area converted ha & Loss of core forest \\
Year & Permitted & Drilled & Producing & & ha & $\%$ \\
\hline 2010 & 98 & 40 & 22 & 232 & 971 & -0.3 \\
2012 & 224 & 159 & 80 & 1,697 & 7,407 & -2.3 \\
2014 & 305 & 214 & 162 & 2,588 & 10,906 & -3.4 \\
2016 & 333 & 234 & 183 & 2,689 & 11,527 & -3.6 \\
\hline
\end{tabular}

${ }^{\mathrm{a}}$ Based on PA DEP permitted, SPUD, and production data. 
Fig. 1 Lycoming County showing Marcellus shale play (light gray), public land (dark gray), and the location of pad infrastructure (well pad, water impoundment, compressor station, etc.; white circles) and linear infrastructure (pipeline, new access road, expanded road; dark lines) associated with shale gas development as of April 2016 (upper map) and location of well pad infrastructure as of April 2016 (black dots) and Lycoming County (dark gray) within the Marcellus shale play (light gray) in Pennsylvania (lower map).

742 Fig. 2 Average number of permitted wells per pad ( \pm SE) by landowner in Lycoming County, 743 Pennsylvania.

745 Fig. 3 Change in area of forest fragmentation class by landowner resulting from shale gas 746 development through April 2016, Lycoming County, Pennsylvania. Within forest class, the 747 proportion of area converted per class is presented relative to the total land area prior to 748 development (i.e., 2005) within that class on public or private land.

750 Fig. 4 Average width ( \pm SE) for gathering pipeline right-of-way (ROW) by landowner and road 751 collocation status (collocated with road [public $n=20$, private $n=20$ ]; not collocated [public $=$ 752 15, private $=20]$ ), Lycoming County, Pennsylvania. Collocated ROW contains both pipeline and 753 gas access road within shared corridor. 
Fig. 5 Predicted loss of core forest (ha \pm SE) resulting from the completion of shale gas wells on existing and permitted pads $(n=110)$ that vary by the type of infrastructure required to bring the well on line (pad, pipeline, or both pad and pipeline), Lycoming County, Pennsylvania.

759 Fig. 6 Predicted loss of core forest (ha \pm SE) resulting from the completion of shale gas wells on 760 existing and permitted pads $(n=110)$ by $(A)$ distance from well to nearest pre-existing pipeline 761 (m) and (B) proportion of core forest within $2 \mathrm{~km}$ surrounding pad, Lycoming County, 762 Pennsylvania. 


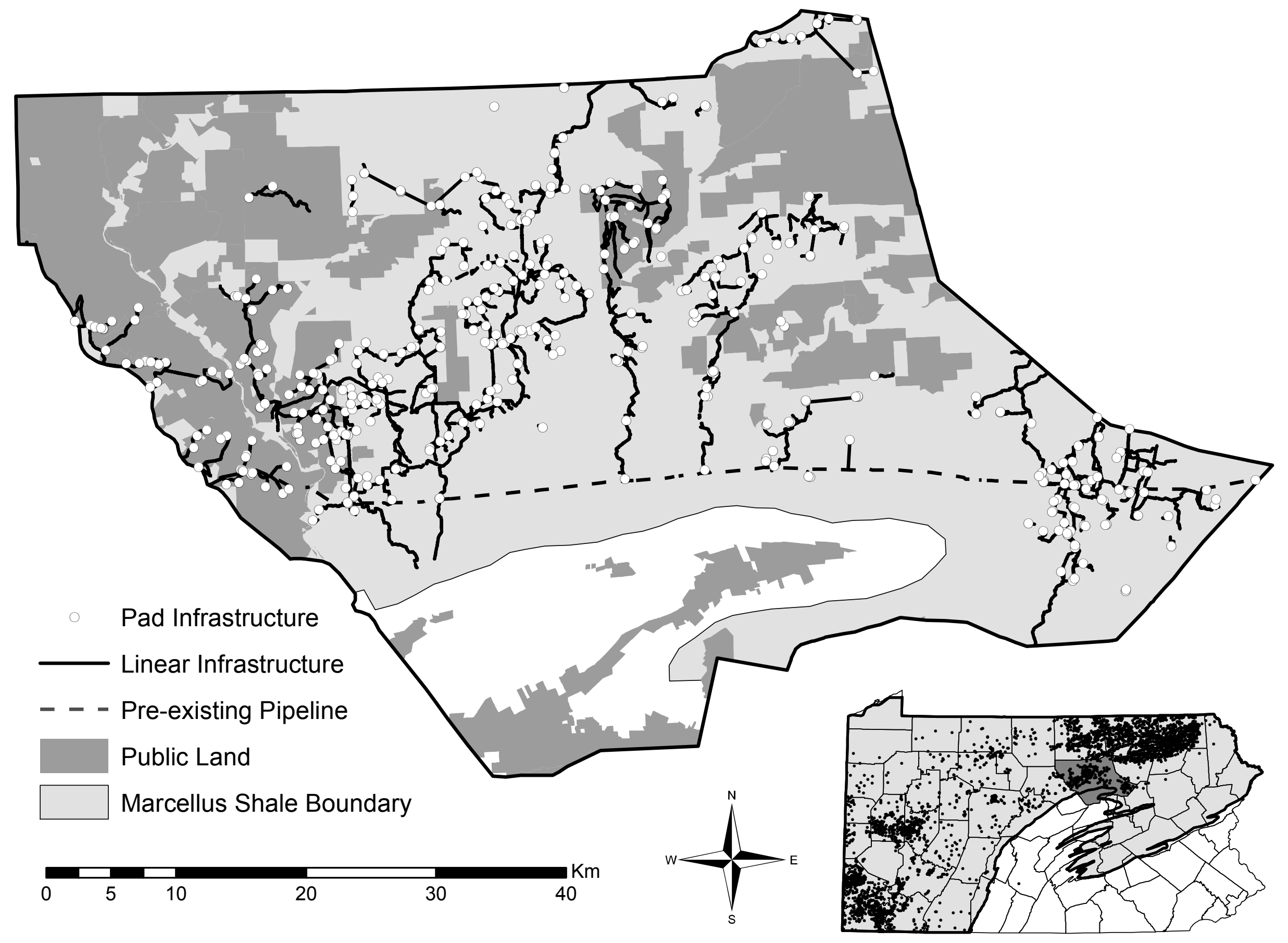




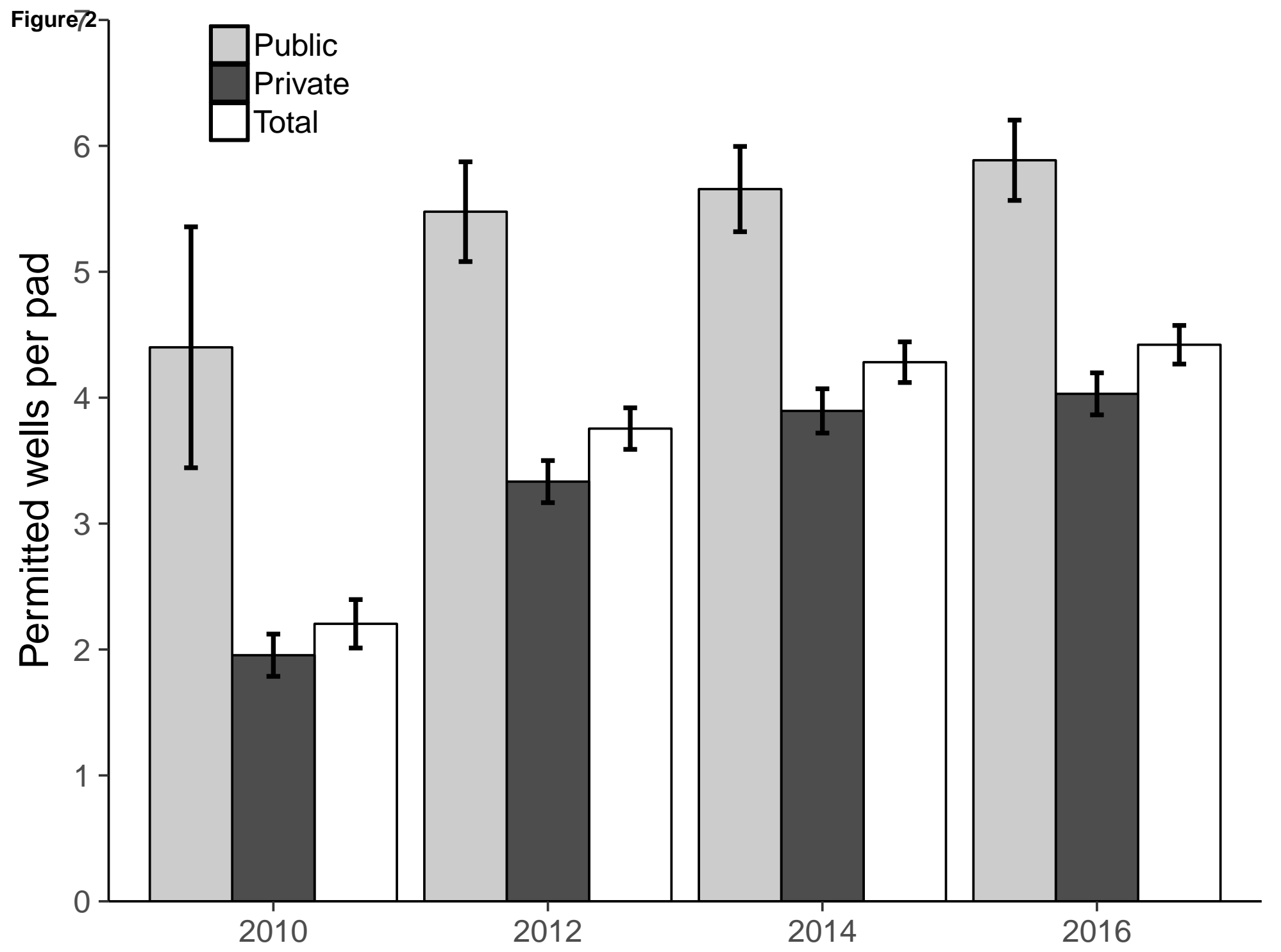




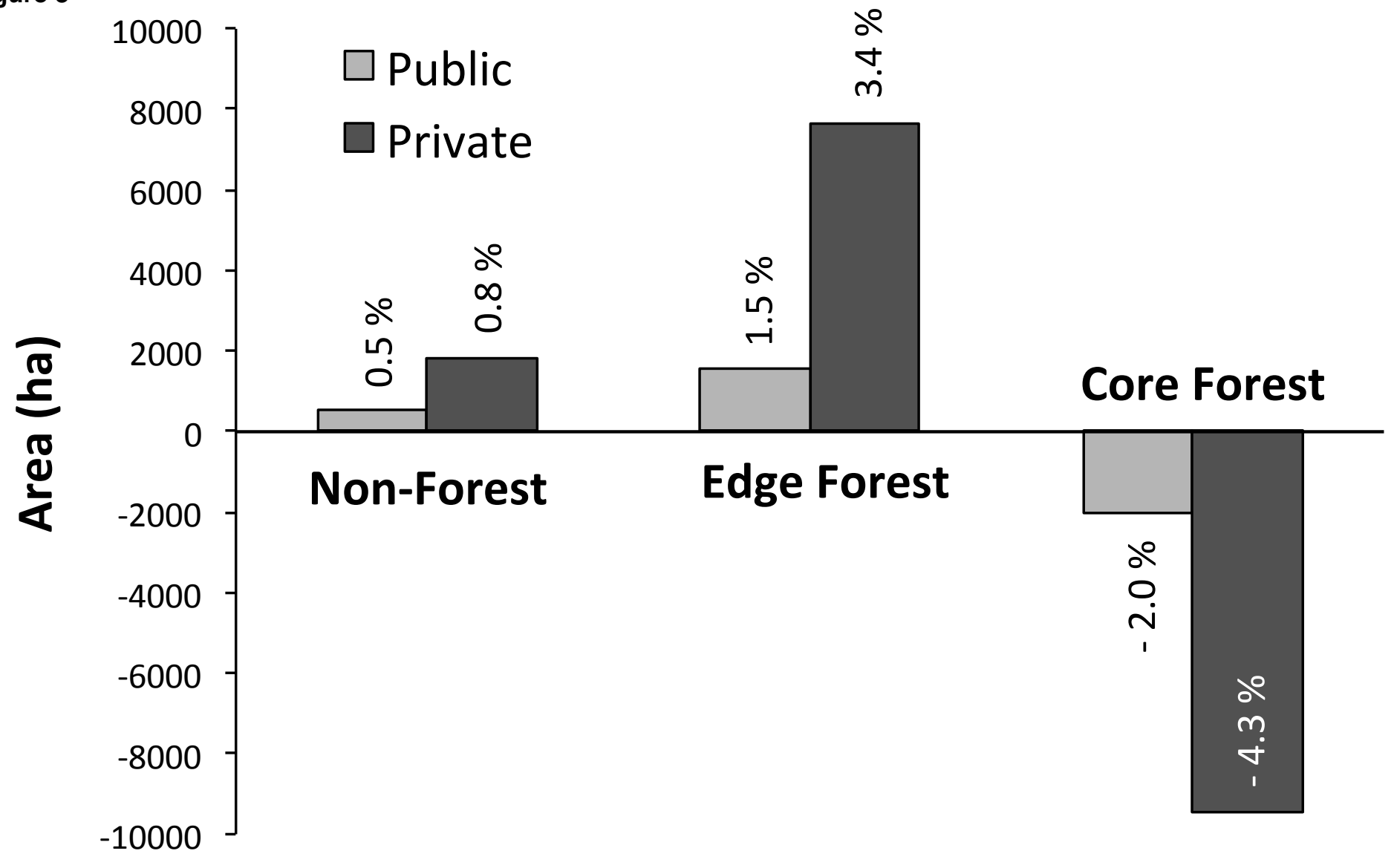


Figure 45

Public

Private

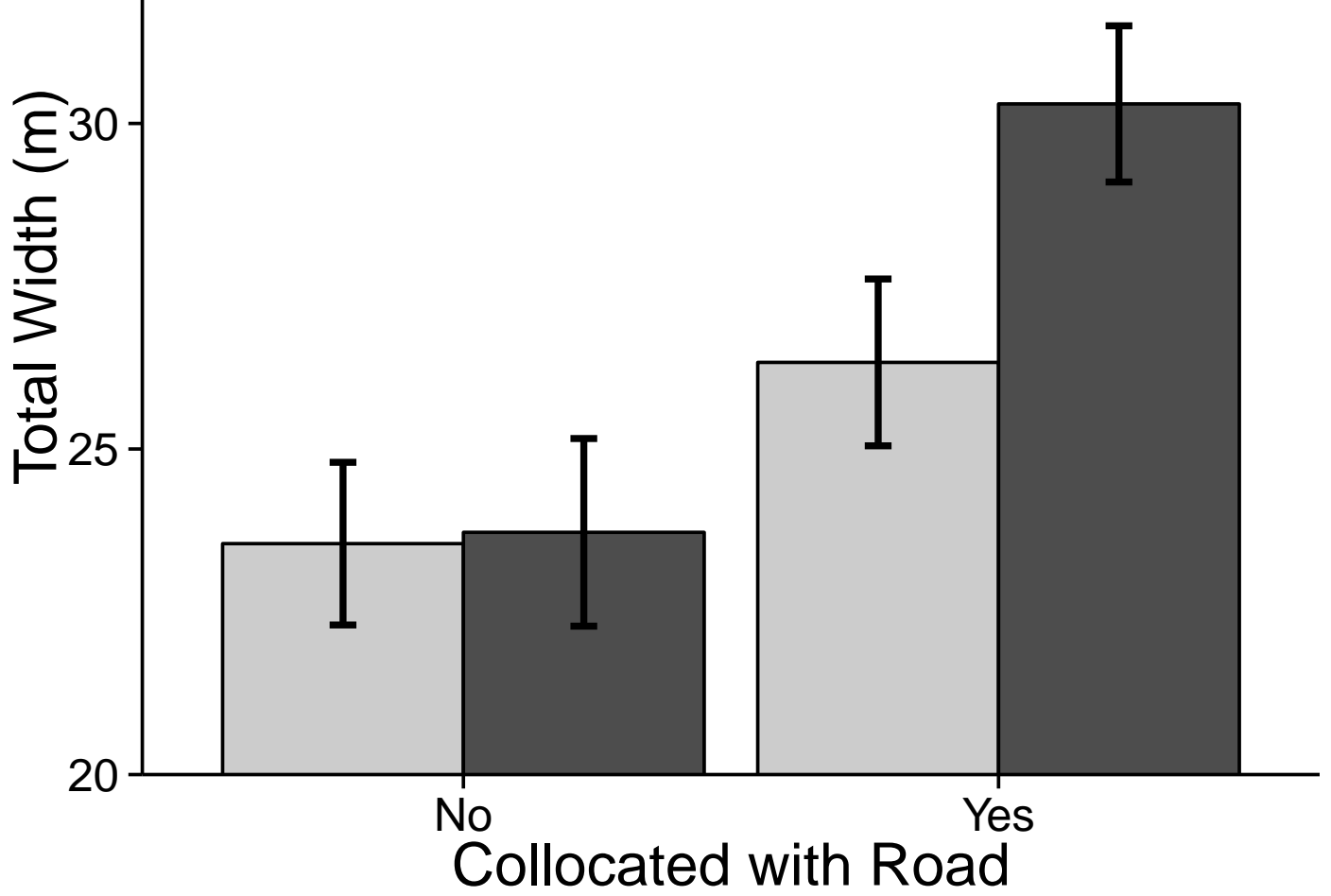




\section{Figure 5}

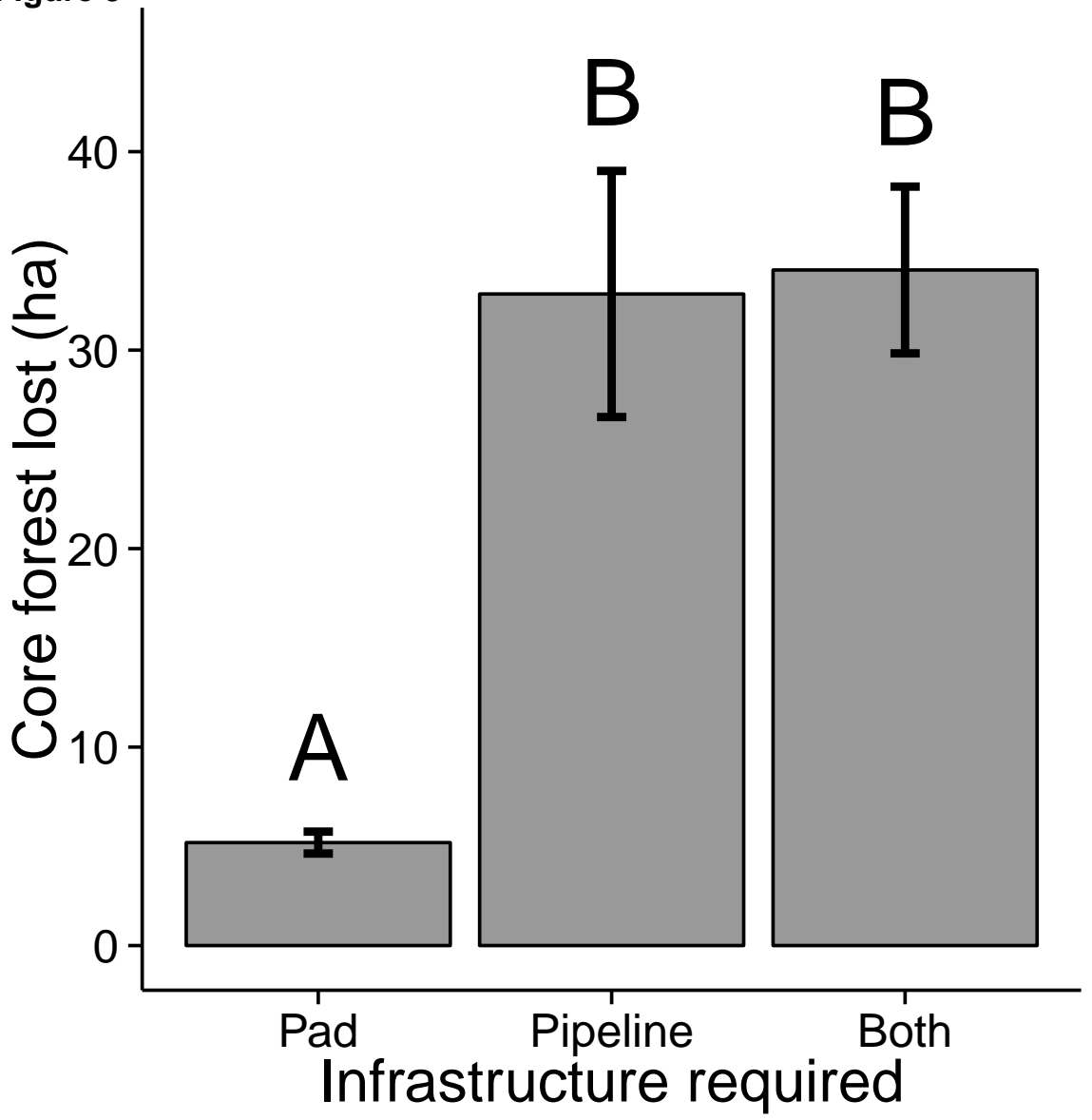


Figure $6 \mathrm{~A}$

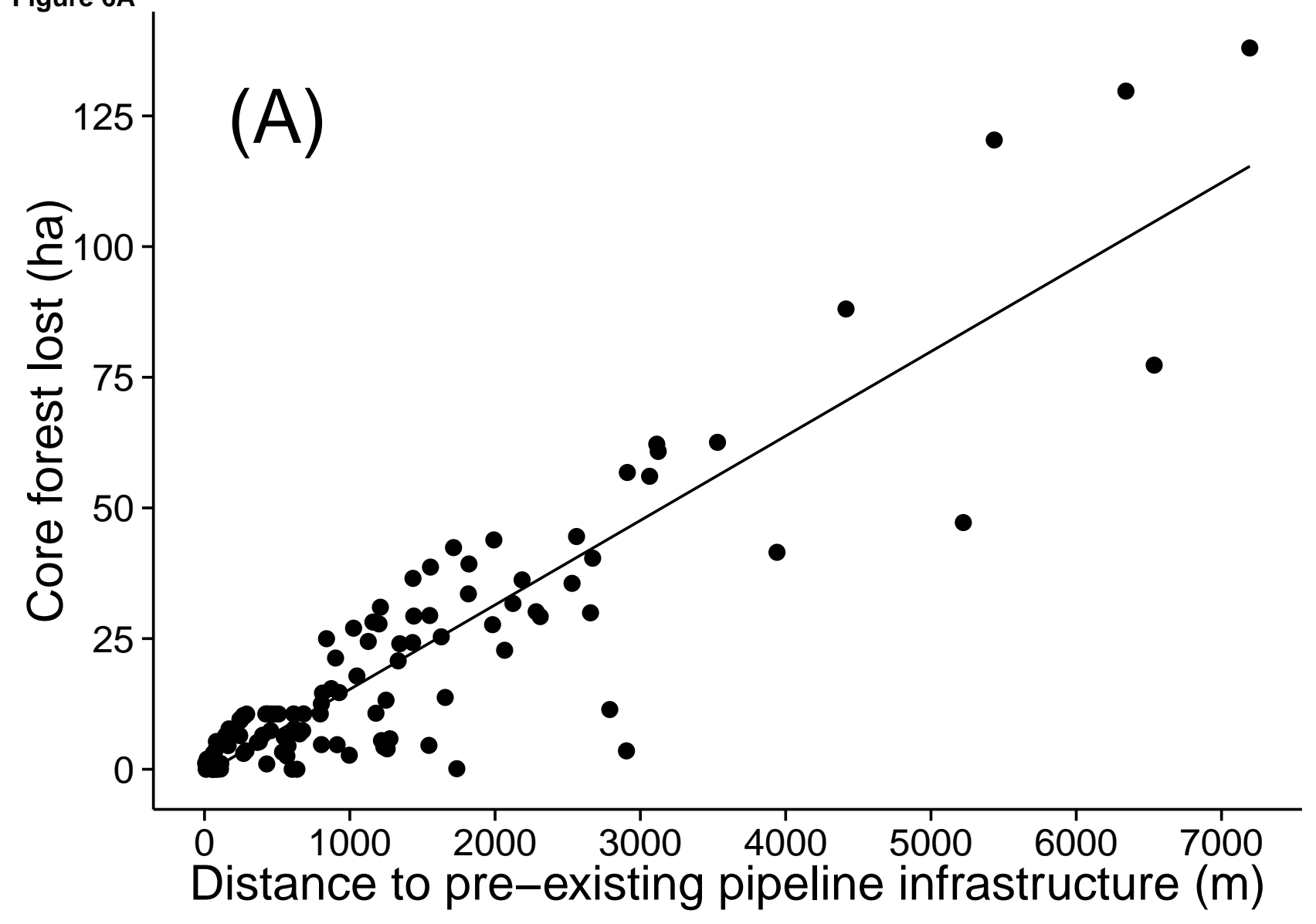


Figure 6B

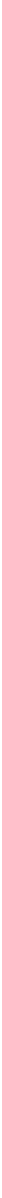

